\title{
Rose-Anaïs Weeber
}

\section{Crimson Peak: Guillermo del Toro's Visual Tribute to Gothic Literature}

\begin{abstract}
Through films and TV series such as The Woman in Black (2012), Twilight (2009), Ripper Street (2013) and Penny Dreadful (2014), the twenty-first century is the witness of the emergence of a Neo-Gothic imagination. The fascination for ghosts, vampires and werewolves has never truly disappeared since the eighteenth century, but found a new modernity in the twenty-first century. This trope also inspired Mexican director Guillermo del Toro for his movie Crimson Peak (2015), in which he explores the themes and codes of a nineteenth cen-tury decadent Gothic romance but deflects them in order to create his own conception of a ghost story. In this paper I will discuss how del Toro, while being faithful of the Gothic tradi-tion in its form and intrigue, injects the twenty-first century through visuals and plot twists.
\end{abstract}

Keywords: Guillermo del Toro; Gothic; Film; Romance; Crimson Peak; Haunted House; Chosts.

\section{ROSE-ANAÏS WEEBER}

Université Paris Sorbonne IV, Paris, France rose-weeber@hotmail.fr

DOI: $10.24193 /$ cechinox.2018.35.07

\section{Introduction}

Tnspired by Gothic literature, and more 1 specifically the decadent Gothic of the nineteenth century, the acclaimed and visionary director Guillermo del Toro (born 1964) created his own Neo-Gothic romance, Crimson Peak ${ }^{1}$. Released in 2015, it explores the themes of the great Gothic tales of the past: a tragic love story, a haunted mansion, ghosts and a terrible villain. The story is set in 1901, in the New industrial city of Buffalo, New York. It follows the story of Edith Cushing who, falling in love with a mysterious British baronet, Sir Thomas Sharpe, sails to England to live in her husband's family estate. Without disclosing too much of the plot, it is important to note that del Toro wanted Crimson Peak to, not only re-create the atmosphere of a Gothic romance - a word he employs himself to describe his film ${ }^{2}-$ but also to "subvert some of the things that make a Gothic romance a Gothic romance in the same way that Pan's Labyrinth is an anti-fairy tale fairy tale." "Therefore, the director pays tribute to the great writers of the past, such as Edgar Allan Poe and Henry James, but he also reworks the Gothic 
literary structure and adapts it into visual forms. How representative is Crimson Peak of the Neo-Gothic of the twenty-first century? Del Toro and Matthew Robbins wrote their own Gothic tale, cramped with quotes from the past, and adapted it to the screen. Crimson Peak positions itself as an heir of the great Gothic novels, as an illustration of such stories. This is clearly stated through the opening of Crimson Peak and the image of a book - similar to the illustrated books of the nineteenth century, with a blue cloth cover ornamented with the red title "Crimson Peak" - which opens on an illustration of the city of Buffalo. This illustration animates itself into a set of the movie, and the beginning of the story of Crimson Peak. As del Toro assumed the role of an illustrator, he gathered a lot of visual inspiration from the period, from the Pre-Raphaelites Brotherhood to the Sublime. He is proposing a twentieth century intrigue with a twenty-first century twist: "I thought it would be interesting to make it a little more stylized and perverse (to bring it back to a new generation). And also to heighten a couple of elements that, traditionally, remained hidden beneath the surface: sex and violence ${ }^{4}$."

In this article I will discuss how Guillermo del Toro creates a Neo-Gothic movie highly influenced by Gothic themes and codes of the nineteenth and twentieth centuries through both the script and the visuals of Crimson Peak. First, we will look at the heroine's journey and how it responds to the portrayals of the feminine heroine in Gothic literature. Then, we will discuss the themes of the haunted mansion and the ghosts and how he transformed them into elements of modernity. Lastly, we will focus on the characters of the villain and of the double, as descendants of the great Gothic literature.

\section{The Tale of a Metamorphosis}

The heroine of Guillermo del Toro's
Gothic romance is named Edith Cushing (interpreted by actress Mia Wasikowska). She is the daughter of Mr Carter Cushing, an industrial man who raised his daughter alone after the death of his wife. Edith has been, since her childhood, very receptive to the supernatural and, most importantly, to ghosts. It was when she was ten years old that she first saw the ghost of her mother, which was a "pivotal moment which started her fascination with ghosts, death, and mortality ${ }^{5}$."

Throughout the film, del Toro plays with the character of Edith as a true Gothic hero who rebirths herself through pain and deception, but he also depicts a truly independent figure which is a modernistic approach of the feminine in his Neo-Gothic romance.

From the beginning of the movie, del Toro sets the character of Edith as a strong and independent woman. She is an aspiring writer and is trying her best to achieve her goal. Edith is, therefore, an anti-Gothic heroine. Indeed, as defined by William Patrick Day in his work In the Circle of Fear and Desire: A Study of Gotbic Fantasy, the heroine of the Gothic novel is a passive one, she is "the passive victim of another " and she "accepts domination, accepts the position of masochist, because the assertion of her identity, tied up as it is with the qualities of passivity and respectability, demands she accept this role." It is true that Edith is defined by some of these characteristics, and resembles Charlotte Brontë's 
Jane Eyre (1847), whom Mia Wasikowska interpreted in 2012. Jane Eyre moves from home to home and is continually treated as a mere servant, until she moves into a large estate and find the love of $\mathrm{Mr}$ Rochester. In a similar way, Edith is living with a rather controlling father, she wants to become a writer but quickly changes her text when facing critics, and most importantly, after the death of her father, she seems to move from her dad's domination to Thomas' as if she was a mere object or a child. Once she moves into Allerdale Hall, this situation does not really change. She does not dare to impose her position in the household as she does not seem to feel legitimate to do so. Indeed, she acts the same way as the second Mrs de Winter in Hitchcock's Rebecca. Del Toro made it clear that he was strongly inspired by Daphne du Maurier's story, and Edith follows the same tracks as the heroine of the 1938 book and the 1940 movie. Newly wed, Mrs de Winter is constantly reminded of $\mathrm{Mr}$ de Winter's first wife, Rebecca, and how superior she was to her. In del Toro's story, Edith is not undermined by a mere memory but by Thomas' jealous sister, Lucille. Lucille makes sure that Edith understands that she is not at all welcome in the Sharpe's circle, and that she is no match for her. In the incredible scene in Buffalo when Edith and Lucille are confronted with the death of many butterflies in the park, Lucille hints to Edith that she is similar to these butterflies by caressing her cheek while muttering: "Beautiful things are fragile. At home, we only have black moths, formidable creatures to be sure, but they lack beauty, they thrive on the dark and the cold. [They feed on] butterflies, I'm afraid." This passive aggressive discourse is what Edith will submit to most of her time at Allerdale Hall, until she finally discovers who she really is by freeing her own sexuality.

Guillermo del Toro evokes, in a subtext, both Perrault's Bluebeard and Bram Stoker's Dracula (1897) in the transitional scene of the movie where Edith stands up for herself by asking Thomas not to return to Allerdale Hall one night. They stay in a lodger's room and have their first sexual intercourse, away from Lucille and the past. In Bluebeard, this sexual maturity is hinted with the key penetrating the forbidden door and being stained by blood, which is a beautiful evocation of the female's first sexual intercourse. In the tale it is from this moment onward that the wife emancipates herself and refuses to be submitted to her husband. Gothic author Bram Stoker also describes this rebirth following the forbidden sexual act of Jonathan Harker after he disobeys the count's warning and falls asleep in one of the rooms of the castle. $\mathrm{He}$ is soon visited by Dracula's brides who invite Jonathan to join them in a prohibited sexuality which lights a fire of desire and passion inside him. After this scene he seems to free himself from the social norms he has tried to follow all his life. In Crimson Peak, the sexual intercourse between Edith and Thomas is the turning point of the intrigue, a cathartic moment for the heroine. It is right upon their return that Edith dares to steal the key from Lucille and discovers the dreadful family secrets which bound the Sharpe siblings to their home.

Edith's journey is one from a little girl to a young woman. In the beginning of the movie, when Thomas is summoned to break Edith's heart, he throws at her some truths about her book, and more generally about herself which are hard to swallow: 
The pain, the loss, it's clear that you've never lived it yourself. What do you dream of? A kind man? A pure soul to be redeemed? A wounded bird you can nourish? Perfection. Perfection has no place in love Edith. (...) You know precious little of the human heart, or love, or the pain that comes with it. You're nothing but a spoiled child!

Unfortunately, this statement cannot be denied, she is a child who has been overly protected and spoiled by a father who lost his wife and had only a daughter left. She is a pure heart, as most of the Gothic heroes and heroines are, she is a projection of what society or family deems she should be. Guillermo del Toro enhances this characteristic through the heroine's visual traits. One of the main visual inspirations for Edith was the painting The Bridesmaid ${ }^{8}$ by John Everett Millais (1851). With her imposing blond hair circling her face, the bridesmaid is waiting for true love while wearing the orange blossom on her breast, symbol of chastity ${ }^{9}$. It is only when faced with horror and with life's experiences; after detaching herself from the parental figure and gaining her independence, that she can fully become who she is meant to be. "The descent into the Gothic underworld becomes a descent into the self in which the protagonists confront their own fears and desires and are transformed, metamorphosed, doubled, fragmented, and destroyed by this encounter ${ }^{10}$."This transition is visually transcribed, at the end of the film, when Edith is chased down the dark and bloody clay pit, in the mansion's abyss and, in a desire to save herself, re-emerges into the outside world, into a snow white fog:
I wanted the contrast between the interior set and the exterior in the fog to be a big shock when Edith comes out of this oppressive, womb-like space into limbo. I really liked the character birthing herself into a woman, and there was no better metaphor than to go from this very interior set to this bleak white limbo. Visually, that's a big journey. ${ }^{11}$.

However, the rebirth of the heroine, in the tradition of Gothic literature, does not seem to be such a clear transition from evil to good, indeed as William Patrick Day describes: "[t]he Gothic world, like a black hole in space, allows no energy to escape, but traps it in a closed system. Action can never be progressive, only circular; whatever the protagonist tries to do, his action must result in his own disintegration ${ }^{12}$." Though Crimson Peak can be seen as a Gothic tale ending with the salvation of its characters, one can wonder if Edith has permanently escaped the horror of Allerdale Hall or if she is forever doomed. The horror she witnessed, the physical and psychological poisoning she suffered and the betrayal of her love seem to have left Edith in an altered state. At the end of the movie, this pure woman, always depicted as the opposite of Lucille, is stained by the blood of the murder she committed. Her dress, her hands echo the great Macbeth after he, who has always been honest, kills the king and mutters "This is a sorry sight ${ }^{13}$," while looking at his hands, stained with blood. Edith is marked by her crime and perpetuates the violent cycle of Allerdale Hall. If we look carefully, it almost seems that Edith is, herself, becoming a part of the place after the Sharpe's auto-destruction. Once Lucille is dead, Edith and Alan McMichael walk away from the mansion, 
toward its open gates, but the last vision we have of Edith is her face, turning back to the house, to the past. We never see her truly pass the gates into the outside world, so we are left with Edith, still in the estate, looking at it in a last gesture of recognition. Moreover, another element which corroborates Day's description of the Gothic world as a cycle repeating itself is the construction of the movie itself. Del Toro opens and closes Crimson Peak with the exact same scene and dialogue: "ghosts are real. This much I know." By doing so, he hints that the whole movie is a never-ending re-enactment of Edith's emancipation, of the violence she lived in Allerdale Hall. Del Toro used the same composition in his Pan's Labyrinth (El Laberinto del Fauno, 2006) where the movie opens and closes with the death of the heroine, making it just a glimpse of Ofelia's imagination. "The extended flashback that lasted the entire movie has taken up only a second in the "real" timeline of this story - a neat demonstration of the collapse of space and time in the supernatural reality that del Toro has situated below, not above, the material world ${ }^{14,}$ This is reinforced by the last image of the movie which mirrors the opening scene: Allerdale Hall fades into a sketch of a book, which closes and these words are seen for the first time "Crimson Peak by Edith M. Cushing". Was it all the mere literary imagination of Edith or an autobiography enhanced with ghosts?

\section{It All Starts with a Haunted Mansion}

$\mathrm{F}$ rom The Castle of Otranto (1764) to The Fall of the House of Usher (1840), Gothic literature often features haunted mansions. Allerdale Hall is the main set of Crimson Peak and gives its name to the movie (as it is called by the mine workers). Similar to Edgar Alan Poe's The Fall of the House of Usher, the old family estate seems to come alive, to the eyes and ears of the new-comer. Guillermo del Toro wanted the house to be a monster, a moving and evolving creature. Unsatisfied with pre-existing sets, del Toro and his team built the whole house, from the clay mines to the attic, in order to fit exactly their imagination: a great Gothic oppressive house which is slowly killing its inhabitants. Therefore, the purpose was to visually transcribe this monstrous and devouring aspect of the mansion. Intertwining several architectural styles, from Medieval to British Gothic-revival, the house alternates between oversized spaces and exaggerated features on one side, and low ceiling and oppressive rooms on another. Del Toro's idea was to create a house which was "beautiful but suffocating ${ }^{15}$." The grand foyer impresses Edith with its monumental heights but soon she discovers a darker side to the house. It has low and decrepit ceilings (del Toro built them according to the actor's height in order to create an impression of them being crushed by the house); multiple spikes pointing towards the characters, whether in the master bedroom or in the beautiful dark corridor, looking like weapons of torture; and chairs built in different sizes in order to swallow the characters or, on the contrary, make them feel bigger, depending their emotional state. Ultimately, the purpose was to make the characters and especially Edith - appear as victims of the monstrous presence of the house, as "a small insect amidst its vast space ${ }^{16}$." Moreover, the construction of the house also involved building interconnected spaces, much like in The Shining (1980) by Stanley 
Kubrick. At the same time that it enables a fluidity of film-making, is also gives, to the viewer, the impression that the house is, in fact, a labyrinth devoid of any exit for the characters to escape. In addition to creating an imposing and menacing structure of the house, del Toro was highly inspired by The Fall of the House of Usher by Edgar Alan Poe in his desire to make the mansion alive through wind and thunder. In Poe's short story, the characters are horrified by the screams which seem to travel around the house, in remembrance of the late Miss Madeline of Usher. Guillermo del Toro borrowed this element - but not only - to use in his Gothic romance. In one scene, the night of Edith's arrival, she is alone with Thomas in the master bedroom and she hears a terrible scream coming from the house, Thomas simply comments: "It's the east wind. The house breathes. It's ghastly, I know." Del Toro was also inspired by the house of Usher and its crack in the wall "extending from the roof of the building, in a zigzag direction, to the base ${ }^{17}$." However, in Allerdale Hall, the crack is coming from below ground, from where the secrets are hidden from sight. Indeed, upon her arrival in the mansion, Thomas warns Edith to "never, ever go below [the ground level]." The clay pits acquire then, an aura of secrecy and curiosity for Edith, echoing Bluebeard's wife who is forbidden access to the room where the previous wives' corpses are stored, or Dracula where Jonathan Harker is warned not to wander around the house and fall asleep, as his host's luscious brides are waiting to suck his blood:

Let me advise you, my dear young friend - nay, let me warn you with all seriousness, that should you leave these rooms you will not by any chance go to sleep in any other part of the castle. It is old, and has many memories, and there are bad dreams for those who sleep unwisely. ${ }^{18}$.

Of course, all these three heroes succumb to temptation and enter the forbidden space. It is, for Bluebeard's wife and Jonathan Harker a truly traumatizing experience, but for Edith, it is the first step toward her rebirth, and her escape from the monstrous. Del Toro definitely looks at the Gothic tradition, but chooses, as in most of his movies, to turn the monster into a figure of goodness. He wants to transform the viewer's perception of what is deemed scary into a feeling of acceptance. Therefore, we realize, as the intrigue advances, that the house is not so terrible, and is, in fact, suffering as much as Edith. It is a house which bleeds and suffocates. As Tom Sanders, production designer, describes "Wherever we had blood coming out, I would have scenic go in and make it look like the wall was bruised first, then rotted, then bleeding. It was the advanced stage of death. Nice and twisted ${ }^{19}$." The house is the physical symptom of all the sins of its inhabitants. It reminds us of Oscar Wilde's The Picture of Dorian Gray (1890) in which the painting of the young sinner rots and ages as the hero experiences moral taboos and deviations. In Crimson Peak the mansion absorbs, on one hand the sin of the multiple sexual intercourses between Lucille and Thomas, but also all the crimes which have been perpetrated within its walls. It is ironic to see that the siblings murdered three women with large estates in order to save the house and put it back together, but as Edith enters the scene, the 
house seems as bad as ever, as if the sins and violence were catching up with the upkeep. The house is slowly sinking into the blood-coloured clay pits, in what del Toro calls "the rotting womb of the beast ${ }^{20}$," the very place where the corpses are decaying. The mansion is a place of death which can never rise back from the bones of its victims and which swallows whoever enters it. Indeed, over the years Lucille and Thomas ended up becoming extensions of the house themselves. The costume designer, Kate Hawley, under del Toro's directives inserted elements of the house in the siblings' clothes. Both of them are mostly dressed in blue clothes, matching Allerdale Hall's walls, and the Corinthian floral designs on the columns of the house find an echo is the floral details of Lucille's blue dress.

In del Toro's Neo-Gothic fiction, the mansion is not solely inhabited by the Sharpes, but also by a few ghosts, victims of the living. Crimson Peak positions itself as an heir of the great tradition of the Gothic ghost stories of the nineteenth century, which emerged with the rising interest for a new imagination, for a fantasy land where the reader could escape their everyday industrial life but also, with a desire to express its fears and taboos, under the covert of fiction.

\section{Between the Living and the Dead}

I $n$ response to the industrialisation of society, the importance of morality, religion and rationalism from the eighteenth to the twentieth century, people's craving for imagination widened and spirituality, spiritism and fiction gained greater interest. Gothic fiction expressed these transgressive ideas though authors such as Edgar Alan Poe, Henry James, W. B. Yeats and Sheridan le Fanu. Guillermo del Toro as a true Neo-Gothic director, created his own "old fashioned Victorian ghost story ${ }^{21}$ " within the walls of Allerdale Hall, with the presence of supernatural forces, and a heroine who is particularly sensible to them. Edith first encounters her mother's ghost at the age of ten, and discovers several others in her husband's mansion. In traditional Gothic stories, ghosts and the undead are the evil ones, they are the monsters manufactured by humans' cruelty. Such as Victor Frankenstein's creature and Madeline Usher, they want to take revenge from the living. In Crimson Peak, however, del Toro departs from this tradition, as his ghosts are helpers, protectors of the pure Edith. They are, of course, visually horrifying at first, but soon reveal themselves to be peaceful spirits. Del Toro's ghosts are colour coded. The first one we get to see is Edith's Mother warning her daughter against "Crimson Peak". She is a black ghost, because she died of Black Cholera. Then we encounter, what Mark Salisbury named "the three brides of Bluebeard ${ }^{22}$ " and Beatrice Sharpe, the mother. All four ghosts are red, the colour of blood, of sin, of murder. Del Toro created these visually innovative ghosts on purpose, in order to renew the old tradition of black and ectoplasmic ghosts: "One ghost could be white, one ghost could be black, and all the murdered ones are red and are linked to the clay. I have never seen ghosts that look like that. I thought it would be interesting to play with, because it would make them visually very beautiful and powerful, but also very now ${ }^{23 . "}$ Del Toro's desire was, then to renew the tradition of ghost stories by 
rendering them more actual, more surprising and horrifying to the twenty-first century public. Indeed, his ghosts are tangible and half way between the physical and the underworld, as they are able to touch Edith. The red ghosts, as we mentioned above, are guiding Edith, which can be explained by the fact that she is not afraid of them, she is not rejecting them. On several occasions she is startled at first but then, she calls them out: "If you're here with me, give me a signal. Touch my hand." The ghosts are visually depicted as victims, and for some of them, as religious icons which makes the viewer understand that there is no evil in them and that they are not the ones to fear. They all show the scars of the violence they suffered: Margaret's ghost has the upper part of her skull completely destroyed; Pamela's is crawling miserably on the floor trailing the remnant of the cord which strangled her, and Beatrice has an axe still implanted in her skull. The most important wife is Enola, as she helps Edith discovering the truth. She seems to have been poisoned. She is the last red ghost which Edith sees, and she is the one portrayed like a Madonna with the ghost of a baby in her arms: "She is like a religious icon floating in her own niche. I made her float high so Edith looks up at her like it's a miracle, like the kids of Lourdes looking at the Virgin Mary. It's a bizarrely Catholic kind of apparition ${ }^{24}$."

Through del Toro's new approach to ghosts, we can wonder who the real villains are. As in his previous movies El Laberinto del Fauno or Hellboy, the director sets the monster and the human in the same physical world, to emphasise the visual monstrosity of the non-humans as opposed to the physical normality and beauty of humans who are, however, the true monsters of his tales. Army Officer Vidal in El Laberinto del Fauno is a truly cruel and sadistic man who ends up killing this own step-daughter, and in Hellboy the eponymous character only desires to be accepted by men, but continues to be rejected by them because of his physical difference. We can also mention del Toro's latest movie The Shape of Water (2018) and its government official Strickland whose heightened masculinity transforms him into a violent and heartless being. As del Toro mentions: "The real horror in all my stories is the human. [...] Ultimately, I want to make movies that tell you the scariest thing on Earth is man. The ghosts may be scary for a moment, but the real horror comes from the human heart and the human spirit ${ }^{25}$."This trope is no different in Crimson Peak, as the intrigue develops and shows Thomas and mostly Lucille as the real evil of the movie.

\section{Doubling the Evil Self}

$\mathrm{F}$ rom her first appearance in Crimson Peak, Lucille Sharpe is identified as the villain. She is seen from behind, sitting at the piano and wearing an imposing red dress (the lace design of the back echoing the protruding spine of the red ghosts). Guillermo del Toro, known for manipulating colours skilfully, used the red in a very precise way. It is only found associated with the ghosts, the red clay, Edith's wedding ring - which was Lucille's mother's ring - and Lucille herself. Red is, therefore, the colour of murder. It identifies Lucille as "the mother of all ghosts ${ }^{26}$." The visual of her character is influenced by villains from several sources. Among those, Mrs Danvers from Hitchcock's Rebecca as 
Lucille is wearing the same hairstyle, and Pre-Raphaelite John Sargent's painting Ellen Terry as Lady Macbeth (1888-9) ${ }^{27}$. The physical resemblance is clear if we note Terry's long hair and her green-blue dress decorated with jewel beetles, which del Toro paraphrased in Lucille's blue velvet dress ornamented with moths. Lucille is the heiress of the manipulative Lady Macbeth but also of the temptress which was a very popular character in Victorian Gothic literature. The lady of darkness ${ }^{28}$ was the embodiment of feminine power, unrestricted sexuality and violence, untamed by society's codes of conduct and patriarchy. Dracula's brides and Carmilla (Sheridan Le Fanu, Carmilla, 1872) are two examples of the Gothic depiction of this female demoness. Lucille is the dark feminine, she assimilates herself to the carnivorous moth and we see her evolution through the loosening of her clothes: from the corseted and sculptural dress to the ethereal moth-like nightgown, Lucille frees her body and shows to the world her true self. She is the dark feminine, Edith's opposite, but also the image of the Gothic double, of the fragmented self. As a consequence of the psychological and physical abuse she suffered as a child, Lucille developed a fragmented personality which she has filled by absorbing parts of her parents, of her brother and of the house. Like Dr Jekyll and Mr Hyde, Lucille is unable to live on her own, away from her other half as she says: "I was alone. I can't be alone." The merging with her mother's personality is shown through the ring and the cameo she wears, as well as through the violence she shows herself capable of, and her piano playing, associated with Beatrice. Lucille is also part of the house, as we mentioned before, given the elements of the house that she wears in her dresses. But the true double figure in Crimson Peak is Lucille and Thomas Sharpe. They are bound to each other, in life and death, and they cannot be parted. Del Toro designed Lucille and Thomas to look like twins - they wear the same colours on their clothes and in their hair - even if we know that Lucille is older than Thomas. They grew up together, suffered together, know only each other and are prisoners of the same past. As one dialogue in the movie expresses it well, they are absolutely dependant of each other:

Lucille: "We stay together. Never apart."

Thomas: "Never apart."

Lucille: "You couldn't leave me. You wouldn't."

Thomas, with tears in his eyes: "I can't. I can't."

Lucille: "I know."

Thomas is the submitted personality who brings the victims to the house and Lucille is the dominant one who kills them. They are both bound by an unnatural sexuality, one which grew from the darkness of the mansion's attic, where they were confined as children. Del Toro, once more, relates to the tradition of Gothic literature and the importance of "the nature of masculine and feminine identity and the nature of the family that shapes that identity. Central to the treatment of these themes are the problem of sexuality, the relation of sexuality to pleasure and identity $(\ldots)^{29}$." It is this exclusive sexuality which ties them together, and the experience of another which drives them apart. Reminiscent of The Strange Case of Dr Jekyll and Mr Hyde by Robert L. Stevenson 
(1886), the double cannot survive. It is an unstable force which will, sooner or later, destroy itself. In Crimson Peak, just as Edith discovers her independence after her first sexual encounter with Thomas, he also realises that he is a being of his own, independent, and free to make his own choices. Therefore, the incestuous connexion with Lucille fades and neither sibling is able to survive. At the end of the movie, Lucille kills Thomas as she cannot tolerate losing a part of her double identity. She is then, killed by Edith, after seeing the white ghost of her dear brother, the ghost of her other half.

Lucille and Thomas are fragmented personalities, similar to Frankenstein's creature who is built with parts of different beings, the siblings are not pure evil. They share with the creature the instinct of self-preservation. Lucille kills in order to protect herself, and to remain forever with her brother, and Thomas is part of the plot because of the love and attachment he has for his sister. Del Toro, then, transforms these villains into victims; victims of the brutality of the past whose only goal is to survive in a world becoming more modern.

\section{Conclusion}

Crimson Peak tells the story of a battle beAtween the moth, England, the past and the butterfly, America, modernity. This tale shows the violence of the industrialisation of the world and the eradication of traditions, fears and taboos of the past. However, modernity never truly wins as it is contaminated by the violence and the poison of the past through the characters of Edith and Alan McMichael, personifications of America, but marked at the end by the blood spilled in Allerdale Hall.
Guillermo del Toro's Neo-Gothic romance also explores the theme of love and all its singularities: the fatherly love of $\mathrm{Mr}$ Cushing for his daughter, the innocent love of Alan for Edith, the passionate love between Thomas and Edith, and the incestuous and monstrous love of Thomas and Lucille. The movie seems to wonder: if a terrible action is made out of love, is it truly despicable? To which del Toro doesn't seem to answer.

Crimson Peak features the terrifying ghosts, the haunted mansion and the monstrous villain, typical elements of the Gothic literature of the nineteenth and twentieth centuries while adding a more modernistic touch. This Neo-Gothic tale doesn't propose a complete alteration of the original Gothic like movies such as Blade (1998), Underworld (2003) or Twilight (2009) which set vampires in modern time America. Del Toro remains faithful to the literature of the past and proposes an illustration of such stories through the use of twenty-first century media.

In his own words, the director describes Crimson Peak as the "most beautiful-looking movie that I've made: it has the special attention to detail in design that my larger productions like Pacific Rim or Hellboy II have, but with the sort of thematic and stylistic proclivities of my European films $\mathrm{s}^{30}$." Del Toro manages to deliver an elegant and terrifying tribute to the Gothic writers of the past centuries while satisfying the modern audience by adding several twists to his intrigue, such as the presence of a strong female heroine, kind ghosts and a non-hidden sexuality and violence.

Unfortunately, Crimson Peak hasn't received a lot of awards and recognition. The screenplay won the Bram Stoker Award and also the Saturn Award for best horror 
film. Indeed, del Toro was disappointed Therefore, it settled the wrong expectations that his movie was marketed as a "hor- for the public and surely has not received, ror movie" instead of a Gothic romance ${ }^{31}$. from the critics, the recognition it deserves.

\section{Works Cited}

Joseph Andriano, Our Ladies of Darkness: Feminine Daemonology in Male Gothic Fiction, Pennsylvania, The Pennsylvania State University Press, 1993.

William Patrick Day, In The Circles of Fear and Desire: A Study of Gothic Fantasy, Chicago and London, The University of Chicago Press, 1985.

Carol Jacobi, "Sugar, Salt and Curdled Milk: Millais and the Synthetic Subject", in Tate Papers, no. 18, Autumn 2012. Online: http://www.tate.org.uk/research/publications/tate-papers/18/sugar-salt-andcurdled-milk-millais-and-the-synthetic-subject. (accessed April 2018)

Victoria Nelson, Gothicka: vampire heroes, human gods, and the new supernatural, Cambridge and London, Harvard University Press, 2012.

David Punter, The Literature of Terror: A History of Gothic Fictions from 1765 to the Present Day, Volume 2, London and New York, Routledge, 2013. [First Published 1996]

Jenelle Riley, "Guillermo del Toro on His Love Affair with Monsters, 'Crimson Peak' and Being a Fanboy”, Variety, 29 September 2015. Online: http://variety.com/2015/film/spotlight/guillermo-deltoro-crimson-peak-monsters-1201603998/ (accessed February 2018)

Mark Salisbury, Crimson Peak: The Art of Darkness, London, Titan Books, 2015.

Britt Salvesen, Jim Shedden, et Matthew Welsh, Guillermo del Toro : Dans l'antre avec les montres. Mes muses, reliques et autres Fétiches, Paris, Huginn \& Muninn, 2016.

\section{Notes}

1. Guillermo del Toro, Crimson Peak, produced by Legendary Pictures and DDY Productions and distributed by Universal Pictures, 2015.

2. "Gothic Romance is a curious beast.It's a mix between the atmospheric of a fairy tale or a horror movie and a love story that reveals the darker side of love." Gillermo del Toro for Jenelle Riley, "Guillermo del Toro on His Love Affair with Monsters, 'Crimson Peak' and Being a Fanboy” in Variety, September 2015. Online: http://variety.com/2015/film/spotlight/guillermo-del-toro-crimson-peak-monsters-1201603998/

3. Mark Salisbury, Crimson Peak: The Art of Darkness, London, Titan Books, 2015, p. 9.

4. Guillermo del Toro in Ibid., p. 6.

5. Mia Wasikowska, Ibid., p. 14.

6. William Patrick Day, In the Circle of Fear and Desire: A Study of Gothic Fantasy, Chicago and London, the University of Chicago Press, 1985, p. 18.

7. Ibid., p.19.

8. John Everett Millais, The Bridesmaid, 1851, Oil on panel, 279 x 203mm, The Fitzwilliam Museum, Cambridge.

9. Carol Jacobi, "Sugar, Salt and Curdled Milk: Millais and the Synthetic Subject", in Tate Papers no. 18, Autumn 2012. online: http://www.tate.org.uk/research/publications/tate-papers/18/ sugar-salt-and-curdled-milk-millais-and-the-synthetic-subject.

10. William Patrick Day, In the Circle of Fear and Desire, p. 27.

11. Guillermo del Toro in Mark Salisbury, Crimson Peak: The Art of Darkness, p. 128.

12. William Patrick Day, In the Circle of Fear and Desire, p. 44. 
13. William Shakespeare, Macbeth, Act II, scene 2, Paris, Flammarion, p. 108.

14. Victoria Nelson, Gothicka: vampire heroes, human gods, and the new supernatural, Harvard University Press, Cambridge and London, 2012, p. 233.

15. Guillermo del Toro in Mark Salisbury, Crimson Peak: The Art of Darkness, p. 93.

16. Ibid.,p. 95.

17. Edgar Alan Poe, "The Fall of the House of Usher" in Selected Tales, London, Penguin Books, 1994, p. 95. [First published in Tales of the Grotesque and Arabesque, 1840]

18. Bram Stoker, Dracula, New York, Barnes \& Nobles, 2012, p. 30. [First published in 1897]

19. Tom Sanders in Mark Salisbury, Crimson Peak: The Art of Darkness, p. 104.

20. Guillermo del Toro in Mark Salisbury, Crimson Peak: The Art of Darkness, p. 80.

21. David Marti, Special Makeup effect) in Mark Salisbury, Crimson Peak: The Art of Darkness, p. 136.

22. Mark Salisbury, Crimson Peak: The Art of Darkness, p. 146.

23. Guillermo del Toro in Ibid., p. 142.

24. Ibid., p. 151.

25. Ibid., p. 136.

26. Guillermo del Toro, "Lucille is the mother of all ghosts. Lucille is the only character you see wearing red in the whole movie and is directly linked to the ghosts." in Mark Salisbury, Crimson Peak: The Art of Darkness p. 116.

27. John S. Sargent, Ellen Terry as Lady Macbeth, 1888-9, oil on canvas, 221 x 114,5mm, London, Tate. 28. Joseph Adriano, Our Ladies of Darkness: Feminine Daemonology in Male Gothic Fiction, Pennsylvania, The Pennsylvania State University Press, 1993.

29. William Patrick Day, In the Circle of Fear and Desire: A Study of Gothic Fantasy, Chicago and London, the University of Chicago Press, 1985, p. 5.

30. Guillermo del Toro in Mark Salisbury, Crimson Peak: The Art of Darkness, p. 7.

31. Britt Salvesen, Jim Shedden, et Matthew Welsh, Guillermo del Toro: Dans l'antre avec les montres. Mes muses, reliques et autres Fétiches, Paris, Huginn \& Muninn, 2016, p. 35. 